J. Dairy Sci. 98:5017-5017

http://dx.doi.org/10.3168/jds.2015-98-7-5017

(c) American Dairy Science Association ${ }^{\circledR}, 2015$.

\title{
Corrigendum to "Short communication: Glucagon-like peptide-2 and coccidiosis alter tight junction gene expression in the gastrointestinal tract of dairy calves" (J. Dairy Sci. 98:3432-3437)
}

M. P. Walker, C. M. Evock-Clover, T. H. Elsasser, and E. E. Connor

The PCR cycling conditions on page 3433 were incorrectly stated. Cycling conditions were $95^{\circ} \mathrm{C}$ for 3 min, followed by 45 cycles of $94^{\circ} \mathrm{C}$ for $15 \mathrm{~s}, 63^{\circ} \mathrm{C}$ for $30 \mathrm{~s}$, and $72^{\circ} \mathrm{C}$ for $30 \mathrm{~s}$.

The authors regret the error.

\section{REFERENCES}

Walker, M. P., C. M. Evock-Clover, T. H. Elsasser, and E. E. Connor. 2015. Short communication: Glucagon-like peptide-2 and coccidiosis alter tight junction gene expression in the gastrointestinal tract of dairy calves. J. Dairy Sci. 98(5):3432-3437. 